\title{
THE EFFECT OF MONETARY POLICY ON UNEMPLOYMENT RATE IN INDONESIA
}

\author{
Hafiansyah Mahadika ${ }^{1}$ \\ Wisnu Wibowo ${ }^{*}$
}

1,2 Fakultas Ekonomi dan Bisnis, Universitas Airlangga

\begin{abstract}
This study aims to determine the influence of monetary policy on the unemployment rate in Indonesia. Unemployment is one of the fundamental problems in the economy. The unemployment problem can be overcome by monetary policy. This study used time series data with the period 1975-2016 using real money demand, economic growth, real interest rates, and real exchange rates as independent variables, and the unemployment rate as the dependent variable. The data used in this study is secondary data obtained from the World Bank. The method used is ARDL (Autoregressive Distributed Lag) which can change a static economic theory to be dynamic by taking into account the role of time explicitly. The results show that in the long run the probability value of the economic growth variable is below the 5\% significance level which indicates that economic growth had a negative and significant effect on the unemployment rate. In the short run, the real interest rate, the real interest rate at lag 1, economic growth at lag 1 and lag 3, and the real exchange rate at lag 1 had a negative and significant effect on the unemployment rate. This indicates that the impact of monetary policy on the unemployment rate is temporary.
\end{abstract}

Keywords: Unemployment Rate, Monetary Policy, ARDL.

\section{RIWAYAT ARTIKEL}

Tanggal Masuk: 28 Januari 2021

Tanggal Revisi:

02 Mei 2021

Tanggal Diterima:

21 Mei 2021

Tersedia Online

25 Juni 2021

*Korespondensi:

Wisnu Wibowo

E-mail:

wisnuwibowo@feb.unair.ac.id

\begin{abstract}
ABSTRAK
Penelitian ini bertujuan untuk mengetahui pengaruh kebijakan moneter terhadap tingkat pengangguran di Indonesia. Pengangguran merupakan salah satu masalah fundamental dalam perekonomian. Masalah pengangguran tersebut dapat di atasi dengan kebijakan moneter. Penelitian ini menggunakan data time series dengan periode 1975-2016 dengan menggunakan permintaan uang riil, pertumbuhan ekonomi, suku bunga riil, dan nilai tukar riil sebagai variabel independen, serta tingkat pengangguran sebagai variabel dependen. Data yang digunakan dalam penelitian ini merupakan data sekunder yang diperoleh dari World Bank. Metode yang digunakan adalah ARDL (Autoregressive Distributed Lag) yang dapat merubah teori ekonomi yang bersifat statis menjadi dinamis dengan memperhitungkan peranan waktu secara eksplisit. Hasil penelitian ini menunjukan bahwa dalam jangka panjang nilai probabilitas pertumbuhan ekonomi di bawah tingkat signifikasi5\% yang menunjukan bahwapertumbuhan ekonomi berpengaruh negatif signifikan terhadap tingkat pengangguran. Sedangkan, dalam jangka pendeksuku bunga riil, suku bunga riil pada lag 1, pertumbuhan ekonomi pada lag 1 dan lag 3, serta nilai tukar riil pada lag 1 berpengaruh negatif signifikan terhadap tingkat pengangguran. Hal ini menandakan bahwa dampak yang diberikan olehkebijakanmoneter kepada tingkat penggangguran bersifattemporer.
\end{abstract}

Kata Kunci: Tingkat Pengangguran, Kebijakan Moneter, ARDL. JEL : E24, E52, E61.

JIET (Jurnal IImu Ekonomi Terapan) p-ISSN: 2541-1470; e-ISSN: 2528-1879 DOI: $10.20473 /$ jiet.v6i1.27100 


\section{Pendahuluan}

Kebijakan ekonomi yang dapat memengaruhi ketenagakerjaan berasal dari kebijakan moneter dan fiskal dengan menggunakan instrumen kebijakan yang dapat memberikan efek kepada penawaran dan permintaan agregat mempengaruhi barang dan jasa (Blanchard, 2017). Pengangguran terjadi karena pasar tenaga kerja memiliki jumlah penawaran tenaga kerja yang lebih besar dibandingkan tingkat permintaan tenaga kerja (Lindiarta, 2014). Indonesia menjadi satu dari banyak negara yang terjangkit permasalahan tingkat pengangguran. Kondisi tingkat pengangguran ini terjadi karena tingkat angkatan kerja tiap tahunnya tidak diimbangi dengan adanya lapangan pekerjaan yang cukup serta kecilnya presentase penyerapan tenaga kerja (Pitartono, 2012). Tingkat pengangguran yang tinggi di Indonesia dapat menyebabkan penurunan tingkat produktivitas tenaga kerja sehingga menyebabkan tingkat pertumbuhan ekonomi mengalami penurunan dan kesejahteraan masyarakat akan tidak sesuai dengan target (Iswanto, 2013).

Pengangguran di Indonesia sulit untuk di atasi karena periode pra krisis ekonomi, Indonesia sudah memiliki kesulitan dalam menghadapi pengangguran dikarenakan pertumbuhan penduduk yang tinggi. Pemerintah Indonesia sudah membuat program dalam mengatasi masalah pengangguran. Beberapa kebijakan yang diterapkan oleh pemerintah Indonesia dalam mengatasi masalah ini diantaranya: kebijakan subsidi, bantuan pinjaman, dan program pelatihan dan kemitraan. Pemerintah Indonesia selama ini selalu memfokuskan kebijakannya untuk program pembangunan. Hal ini dapat diamati dari tingginya kenaikan lapangan kerja. Namun, hal ini tidak cukup karena tidak diimbangi dengan membeludaknya penawaran tenaga kerja yang meningkat seiring berjalannya waktu.

Kebijakan moneter memiliki peranan yang penting dalam mendorong penurunan tingkat pengangguran. Secara teori, kenaikan suku bunga atau penurunan jumlah uang beredar akan memberikan dampak naiknya tingkat pengangguran. Kebijakan moneter akan mempengaruhi aggregate demand dan selanjutnya mempengaruhi tingkat pengangguran. Romer \& Romer (2004) berpendapat bahwa kebijakan moneter telah menjadi variabel kunci untuk mempengaruhi tingkat pengangguran. Hal ini membuktikan kalau reaksi kebijakan moneter akan mempengaruhi perilaku pengangguran dari waktu ke waktu. Kebijakan moneter ekspansi mendorong inflasi yang memiliki hubungan keterbalikan dengan tingkat pengangguran. Dengan terjadinya inflasi maka akan menurunkan tingkat pengangguran.

Pengaruh nilai tukar terhadap tingkat pengangguran tergantung kepada karakteristik pasar tenaga kerja. Secara khusus, Andersen \& Sørensen (1988) berpendapat bahwa jika serikat buruh yang kuat, nilai tukar stabil dapat menyebabkan kenaikan upah yang berlebihan, maka akan mengurangi permintaan tenaga kerja. Belke \& Kaas (2004) juga berpendapat jika karakteristik pasar tenaga kerja memiliki efek yang berbeda-beda tergantung dari tingkat depresiasi nilai tukar yang dapat mendorong perusahaan untuk menunda penciptaan lapangan kerja. Hal ini dapat menyebabkan tingkat pengangguran semakin tinggi. Benazić \& Rami (2016) menganalisis dampak kebijakan moneter di Kroasia terhadap tingkat pengangguran dalam periode tahun 1998-2004 dengan menggunakan metode penelitian ARDL (Autoregressive Distributed Lags) menujukkan bahwa inflasi dan kurs riil berpengaruh signifikan dalam jangka panjang.

Berdasarkan penjabaran pada latar belakang, maka penelitian ini bertujuan untuk menganalisis pengaruh kebijakan moneter terhadap tingkat pengangguran di Indonesia selama masa periode 1975-2016. Penelitian ini menggunakan tingkat permintaan uang riil, pertumbuhan ekonomi, suku bunga riil, serta nilai tukar riil sebagai variabel penjelas yang dapat 
memengaruhi tingkat pengangguran. Variabel penjelas tersebut dianalisis untuk mengetahui pengaruhnya terhadap tingkat pengangguran dalam jangka panjang maupun jangka pendek.

\section{Telaah Literatur}

Pengangguran merupakan sebuah keadaan dimana seseorang yang tergolong dalam angkatan kerja yang ingin mendapatkan pekerjaan tetapi mereka belum dapat memperoleh pekerjaan tersebut (Sukirno, 2003:70). Menurut Kauffman \& Hotchkiss (1999) pengangguran merupakan suatu ukuran yang dilakukan jika seseorang tidak memiliki pekerjaan tetapi mereka sedang melakukan usaha secara aktif dalam empat minggu terakhir untuk memperoleh pekerjaan.

The General Theory menjabarkan pandangannya tentang tingkat bunga yang ditentukan dalam jangka pendek likuiditas (teori preferensi likuiditas). Teori itu menyatakan bahwa tingkat bunga disesuaikan untuk menyeimbangkan penawaran dan permintaan untuk aset perekonomian yang paling likuid yaitu uang. Perpotongan Keynesian merupakan kerangka untuk kurva IS, sedangkan teori preferensi likuiditas adalah kerangka untuk kurva LM. Teori preferensi likuiditas mengasumsikan adanya keseimbangan uang riil yang tetap, yaitu dimana $M$ adalah jumlah uang yang beredar, $P$ adalah tingkat harga, $M / P$ adalah penawaran keseimbangan uang riil.

Model IS-LM adalah interpretasi terkemuka dari teori Keynes. Tujuan dari model ini adalah untuk menunjukkan determinan pendapatan nasional pada berbagai tingkat harga. Ada dua cara pandang terhadap teori ini: Model IS- LM sebagai model yang menunjukkan penyebab pendapatan berubah dalam jangka pendek ketika tingkat harga tetap, menunjukan penyebab kurva permintaan agregat bergeser. Kurva IS menjelaskan setiap hal yang terjadi pada pasar barang dan jasa. Kurva LM menunjukkan setiap hal yang terjadi pada penawaran dan permintaan terhadap uang. Karena mempengaruhi investasi dan permintaan uang, tingkat bunga merupakan variabel yang menghubungkan kedua bagian dari model IS-LM. Pasar barang adalah pasar yang mempertemukan penawaran dan permintaan barang dan jasa. Pasar barang sering diistilahkan dengan sektor riil. Kurva IS menyatakan hubungan antara tingkat suku bunga ( $\mathrm{i}$ atau $\mathrm{r}$ ) serta tingkat pendapatan Nasional $(\mathrm{Y}$ ) yang muncul di pasar barang dan jasa.

Kebijakan Moneter dapat mempengaruhi Kurva LM. Kurva LM menyatakan tingkat bunga yang menyeimbangkan pasar uang pada setiap tingkat pendapatan. Tingkat bunga ekuilibrium juga tergantung pada penawaran keseimbangan uang riil, M/P. Kurva LM menunjukkan kombinasi tingkat bunga dan tingkat pendapatan yang konsisten dengan ekuilibrium dalam pasar keseimbangan uang riil. Kurva LM digambar untuk penawaran keseimbangan uang riil tertentu. Penurunan dalam penawaran keseimbangan uang riil menggeser kurva LM ke atas. Kenaikan dalam penawaran keseimbangan uang riil menggeser kurva LM ke bawah.

Bank sentral meningkatkan jumlah uang beredar akan merangsang ekonomi domestik dan mengurangi pengangguran. Masalah pengangguran telah lama dikenal sebagai salah satu penyakit utama negara berkembang maupun maju (Galí, 2012). Kenaikan pengangguran selalu menyertai pelemahan aktivitas ekonomi. Kebijakan moneter meningkatkan jumlah uang beredar mendorong inflasi dan sesuai teori Philips, maka peningkatan inflasi akan menekan jumlah pengangguran. Keseimbangan makroekonomi secara agregat, dengan kasus naiknya permintaan agregat akan mengakibatkan harga akan naik. Dengan terjadinya inflasi maka untuk memenuhi permintaan, produsen meningkatkan kapasitas produksinya denganmenambah tenaga kerja (dengan asumsi bahwa tenaga kerja merupakan satu-satunya faktor yang 
dapat meningkatkan output). Berdasarkan pernyataan tersebut dapat disimpulkan bahwa jumlah uang beredar dengan pengangguran berhubungan negatif.

Kebijakan moneter dapat berupa beberapa instrumen yang dapat diimplementasikan untuk melaksanakan fungsinya. Kebijakan tersebut dapat berupa pasar terbuka untuk menjual atau membeli surat berharga seperti SBI. Dengan melakukan jual-beli SBI maka bank sentral dapat mengatur jumlah uang yang beredar di masyarakat. Hal ini dapat mempengaruhi terjadinya inflasi dan deflasi. Sedangkan untuk meningkatkan dan menurunkan suku bunga bank dapat menggunakan kebijakan discount rate. Dengan meningkatkan suku bunga maka akan memberikan dampak negatif kepada jumlah uang beredar. Begitu juga sebaliknya, dengan menurunkan suku bunga bank maka akan memberikan dampak positif kepada jumlah uang beredar. Cadangan kas minimal merupakan kebijakan bank sentral untuk menaikkan atau menurunkan minimal dari cadangan kas bank umum. Bila bank sentral menaikkan minimal cadangan kas maka akan mengurangi jumlah uang beredar. Sebaliknya, dengan menurunkan minimal cadangan kas maka akan menambah jumlah uang beredar.

\section{Tabel 1: Rangkuman Penelitian Terdahulu}

\begin{tabular}{|c|c|c|c|c|}
\hline No. & Peneliti & Variabel & Metode & Hasil \\
\hline 1. & $\begin{array}{l}\text { Benazić \& } \\
\text { Rami (2016) }\end{array}$ & $\begin{array}{l}\text { Variabel dependen: Tingkat } \\
\text { Pengangguran } \\
\text { Variabel Independen: Inflasi, } \\
\text { Jumlah Uang Beredar, Nilai } \\
\text { tukar riil, Suku bunga }\end{array}$ & $\begin{array}{l}\text { ARDL (Autore- } \\
\text { gressive Distrib- } \\
\text { uted Lag) }\end{array}$ & $\begin{array}{l}\text { Hasil penelitian ini menunjukkan } \\
\text { bahwa inflasi dan kurs riil berpen- } \\
\text { garuh signifikan terhadap pengang- } \\
\text { guran dalam jangka panjang. }\end{array}$ \\
\hline 2. & $\begin{array}{l}\text { Doğan } \\
\text { (2012) }\end{array}$ & $\begin{array}{l}\text { Variabel dependen: Tingkat } \\
\text { Pengangguran } \\
\text { Variabel independen: } \\
\text { Nilai tukar, pertumbuhan } \\
\text { ekonomi, tingkat inflasi, suku } \\
\text { bunga, pertumbuhan jumlah } \\
\text { uang beredar, dan pertum- } \\
\text { buhan ekspor }\end{array}$ & $\begin{array}{l}\text { VAR (Vector Au- } \\
\text { toregressive) }\end{array}$ & $\begin{array}{l}\text { Hasil penelitian ini menunjukkan ti- } \\
\text { dak ada hubungan jangka panjang } \\
\text { antara variabel independen den- } \\
\text { gan dependen yang digunakan da- } \\
\text { lam penelitian. Hasil penelitian ini } \\
\text { menunjukan bahwa seluruh variabel } \\
\text { independen yang digunakan memi- } \\
\text { liki pengaruh yang signifikan secara } \\
\text { stastistik pada pengangguran. Per- } \\
\text { tumbuhan PDB, pertumbuhan ek- } \\
\text { spor, dan inflasi berdampak negatif } \\
\text { pada pengangguran. Nilai tukar, suku } \\
\text { bunga antar bank, dan pertumbuhan } \\
\text { uang juga berpengaruh negatif pada } \\
\text { pengangguran }\end{array}$ \\
\hline 3. & $\begin{array}{l}\text { Bakhshi \& } \\
\text { Ebrahimi } \\
(2016)\end{array}$ & $\begin{array}{l}\text { Variabel dependen: Tingkat } \\
\text { Pengangguran } \\
\text { Variabel independen: per- } \\
\text { tumbuhan ekonomi, kurs riil, } \\
\text { ekspor, dan impor }\end{array}$ & $\begin{array}{l}\text { ARDL (Autore- } \\
\text { gressive Distrib- } \\
\text { uted Lag) }\end{array}$ & $\begin{array}{l}\text { Hasil penelitian menunjukkan per- } \\
\text { tumbuhan ekonomi, ekspor, dan im- } \\
\text { por tidak berpengaruh signifikan ter- } \\
\text { hadap tingkat pengangguran di Iran } \\
\text { dalam jangka panjang, namun kurs } \\
\text { riil berpengaruh signifikan terhadap } \\
\text { tingkat pengangguran di Iran dalm } \\
\text { jangka panjang. Selanjutnya pertum- } \\
\text { buhan ekonomi serta kurs riil ber- } \\
\text { pengaruh signifikan terhadap tingkat } \\
\text { pengangguran di Iran dalam jangka } \\
\text { pendek. Sedangkan ekspor dan im- } \\
\text { por tidak berpengaruh signifikan ter- } \\
\text { hadap tingkat pengangguran di neg- } \\
\text { ara Iran dalam jangka pendek. }\end{array}$ \\
\hline
\end{tabular}




\begin{tabular}{|c|c|c|c|c|}
\hline No. & Peneliti & Variabel & Metode & Hasil \\
\hline 4. & $\begin{array}{l}\text { Loganathan } \\
\text { dkk. (2012) }\end{array}$ & $\begin{array}{l}\text { Variabel dependen: Tingkat } \\
\text { Pengangguran } \\
\text { Variabel independen: Jumlah } \\
\text { uang beredar sebagai proksi } \\
\text { dari kebijakan moneter }\end{array}$ & $\begin{array}{l}\text { VECM (Vector } \\
\text { Error Corection } \\
\text { Model) }\end{array}$ & $\begin{array}{l}\text { Hasil estimasi dari penelitian ini } \\
\text { menujukkan bahwa jumlah uang } \\
\text { beredartidak berpengaruh signifikan } \\
\text { terhadap tingkat pengangguran. }\end{array}$ \\
\hline 5. & $\begin{array}{l}\text { Akanbi } \\
\text { (2015) }\end{array}$ & $\begin{array}{l}\text { Variabel dependen: Tingkat } \\
\text { Pengangguran } \\
\text { Variabel independen: per- } \\
\text { tumbuhan ekonomi, jumlah } \\
\text { uang beredar, FDI, dan suku } \\
\text { bunga. }\end{array}$ & $\begin{array}{l}\text { VAR (Vector Au- } \\
\text { toregressive) }\end{array}$ & $\begin{array}{l}\text { Hasil penelitian menunjukkan bah- } \\
\text { wa shock pertumbuhan ekonomi } \\
\text { direspon positif oleh pengangguran, } \\
\text { shock FDI dan jumlah uang beredar } \\
\text { direspon negatif oleh pengangguran. } \\
\text { Sedangkan shock suku bunga dire- } \\
\text { spon positif oleh pengangguran. }\end{array}$ \\
\hline
\end{tabular}

Sumber: Data diolah

Benazić \& Rami (2016) melakukan penelitian tentang kebijakan moneter dan pengangguran. Penelitian ini menguji dan menganalisis dampak kebijakan moneter di Kroasia terhadap tingkat pengangguran selama periode Maret 1998 - September 2014. Metode penelitian yang digunakan yaitu ARDL (Autoregressive Distributed Lag). Hasil penelitian ini menunjukkan bahwa inflasi dan kurs riil berpengaruh signifikan terhadap pengangguran dalam jangka panjang.

Doğan (2012) melakukan penelitian dengan topik pengangguran di negara Turki periode 2000 Q1 - 2010 Q1. Penelitian ini menginvestigasi respon pengangguran dari pengaruh variabel makro ekonomi seperti nilai tukar, pertumbuhan ekonomi, tingkat inflasi, suku bunga, pertumbuhan jumlah uang beredar, dan pertumbuhan ekspor. Penelitian ini menggunakan metode VAR karena tidak terjadi kointegritas antar variabel. Hasil penelitian ini menunjukkan tidak ada hubungan jangka panjang antara variabel independen dengan dependen yang digunakan dalam penelitian. Hasil penelitian ini menunjukan bahwa seluruh variabel independen yang digunakan memiliki pengaruh yang signifikan secara stastistik pada pengangguran. Pertumbuhan PDB, pertumbuhan ekspor, dan inflasi berdampak negatif pada pengangguran. Nilai tukar, suku bunga antar bank, dan pertumbuhan uang juga berpengaruh negatif pada pengangguran. Temuan ini juga konsisten dengan kurva Philips yang meramalkan hubungan negatif antara pengangguran dan inflasi serta hukum Okun yang menyatakan hubungan negatif antara output danpengangguran.

Loganathan dkk. (2012) melakukan penelitian tentang dampak kebijakan moneter dengan instrumen jumlah uang beredar terhadap tingkat pengangguran di Malaysia. Penelitian ini menguji dan menganalisis hubungan kebijakan moneter dengan tingkat pengangguran dalam periode 1980-2010. Metode yang digunakan adalah VECM. Hasil estimasi dari penelitian ini menujukkan bahwa jumlah uang beredar tidak berpengaruh signifikan terhadap tingkat pengangguran di negara Malaysia selama periode 1980-2010.

Bakhshi \& Ebrahimi (2016) melakukan penelitian tentang tingkat pengangguran di negara Iran. Tujuan penelitian Bakhshi dan Ebrahimi adalah menguji dan menganalisis pengaruh pertumbuhan ekonomi, kurs riil, ekspor, dan impor terhadap tingkat pengangguran di negara Iran selama periode 1981-2012. Metode penelitian Bakhshi dan Ebrahimi yaitu ARDL. Hasil penelitian menunjukkan pertumbuhan ekonomi, ekspor, dan impor tidak berpengaruh signifikan terhadap tingkat pengangguran di Iran dalam jangka panjang, namun kurs riil berpengaruh signifikan terhadap tingkat pengangguran di Iran dalm jangka panjang. Selanjutnya pertumbuhan ekonomi serta kurs riil berpengaruh signifikan terhadap tingkat pengangguran di Iran dalam jangka pendek. Sedangkan ekspor dan impor tidak berpengaruh signifikan terhadap tingkat pengangguran di negara Iran dalam jangka pendek. 
Akanbi (2015) melakukan penelitian tentang pengangguran di negara Nigeria. Tujuan penelitian ini adalah melihat impulse response dari pengangguran akibat perubahan pertumbuhan ekonomi, jumlah uang beredar, FDI, dan suku bunga. Metode yang digunakan yaitu VAR. Hasil penelitian menunjukkan bahwa shock pertumbuhan ekonomi direspon positif oleh pengangguran, shock FDI dan jumlah uang beredar direspon negatif oleh pengangguran. Sedangkan shock suku bunga direspon positif oleh pengangguran.

\section{Metode Penelitian}

Pendekatan yang digunakan dalam penelitian ini adalah pendekatan kuantitatif. Pendekatan kuantitatif di dalam analisis data dan kesimpulan menggunakan aspek pengukuran atau perhitungan (Musianto, 2002). Penelitian ini menggunakan data time series dengan periode 1975-2016. Penelitian ini menggunakan permintaan uang riil, pertumbuhan ekonomi, suku bunga riil, dan nilai tukar riil sebagai variabel independen, serta tingkat pengangguran sebagai variabel dependen. Data yang digunakan dalam penelitian ini merupakan data sekunder yang diperoleh dari World Bank dengan jumlah total observasi dalam penelitian ini adalah 41 observasi. Objek penelitian yang digunakan dalam penelitian ini adalah negara Indonesia. Negara Indonesia dijadikan objek penelitian karena Indonesia tergolong dalam negara berkembang yang memiliki masalah tingkat pengangguran tinggi yang disebabkan dengan pertumbuhan penduduk yang tinggi. Metode yang digunakan adalah ARDL. Model Autoregressive Distributed Lag (ARDL) merubah teori ekonomi yang bersifat statis menjadi dinamis dengan memperhitungkan peranan waktu secara eksplisit (Karomah \& Suhartono, 2014).

Model ARDL dapat membedakan respon jangka pendek dan respon jangka panjang dari variabel dependen akibat perubahan nilai variabel independen. Model ARDL biasanya dilambangkan dengan ARDL ( $p, q 1, q 2, \ldots, q k)$. $p$ merupakan jumlah lag variabel dependen sedangkan $n$ merupakan jumlah lag variabel independent. Berikut ini adalah model ARDL dalam penelitian ini:

$$
\begin{aligned}
\Delta y_{t}= & a_{1}+\sum_{t=1}^{p} \Delta y_{t-1}+\sum_{t=1}^{p} \beta_{1} \Delta x_{1 t-1}+\sum_{t=1}^{p} \beta_{3} \Delta x_{2 t-1}+\sum_{t=1}^{p} \beta_{4} \Delta x_{3 t-1} \\
& +\sum_{t=1}^{p} \beta_{5} \Delta x_{4 t-1}+\delta_{1} u_{t-1}+\delta_{2} x_{1 t-1}+\delta_{3} x_{2 t-1}+\delta_{4} x_{3 t-1}+\delta_{5} x_{4 t-1}+\varepsilon_{t}
\end{aligned}
$$

Keterangan:

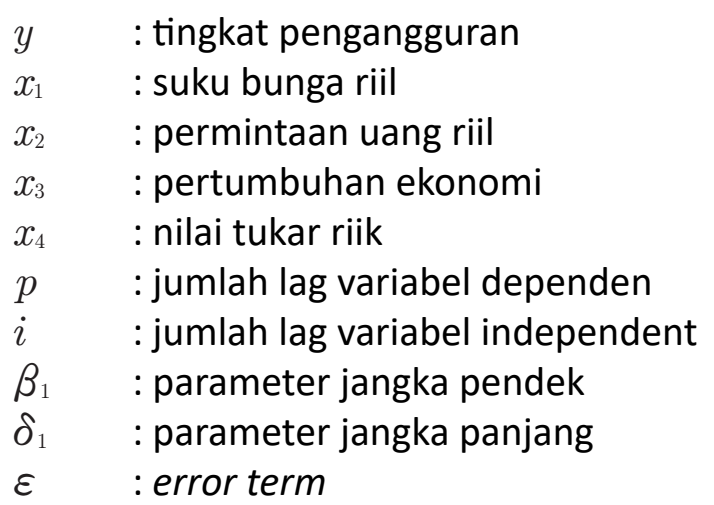

Pengujian untuk menganalisis suatu variabel stasioner atau tidak stasioner dilakukan dengan uji Augmented Dicky Fuller (ADF). Gujarati (2003:449) menjelaskan bentuk persamaan uji stasioner dengan analisis ADF. Persamaan ADF ada dua jenis, tanpa trend dan menggunakan trend. ADF test menganalisis suatu variabel stasioner dan tidak stasioner dengan cara melihat P-Value (Probabilitas) dari ADF. Jika P-Value (Probabilitas dari ADF kurang dari critical 
value, maka tidak terdapat unit root. Begitu juga sebaliknya, jika P-Value (Probabilitas) dari ADF lebih dari critical value, maka terdapat unit root. Ada atau tidaknya hubungan jangka panjang antar variabel dibuktikan dengan Bound test. Pesaran dkk. (2001) berpendapat bahwa kointegrasi Bounds test didasarkan pada F-Statistik. Jika F-Statistik lebih besar dibandingkan signifikasi Bounds maka terdapat hubungan jangka panjang. Penelitian ini menggunakan Uji T untuk menganalisis hubungan antara variabel independen dengan variabel dependen secara parsial. Sedangkan untuk mengetahui hubungan variabel independen dengan variabel dependen secara simultan dilakukan dengan Uji F.

\section{Hasil dan Pembahasan}

\section{Uji Stationeritas (ADF Test)}

Suatu data time series tidak stasioner maka data tersebut menghadapi persoalan unit root. Data yang mengandung unit root maka mengalami spurious regression. Prosedur uji Stasioner pada suatu data dengan menggunakan prosedur uji ADF.

Tabel 2: Uji Stasioner Tingkat Level-Intercept dan First Difference-Trend and Intercept

\begin{tabular}{ccccc}
\hline Variabel & $\begin{array}{c}\text { Prob.ADV } \\
\text { Tingkat Level }\end{array}$ & Keterangan & $\begin{array}{c}\text { Prob. ADV Tingkat } \\
\text { First Difference }\end{array}$ & Keterangan \\
\hline Level Pengangguran & 0,5585 & Tidak Stasioner & 0,0000 & Stasioner \\
\hline Suku Bunga Riil & 0,0000 & Stasioner & 0,0000 & Stasioner \\
\hline Permintaan Uang & 0,9220 & Tidak Stasioner & 0,0001 & Stasioner \\
\hline Pertumbuhan & 0,0009 & Stasioner & 0,0000 & Stasioner \\
\hline Nilai Tukar Riil & 0,1207 & Tidak Stasioner & 0,0000 & Stasioner \\
\hline
\end{tabular}

Sumber: World Bank, diolah

Berdasarkan tabel di atas uji stasioner pada tingkat level hanya dua variabel yang stasioner, yaitu suku bunga riil dan pertumbuhan ekonomi. Sedangkan tiga variabel lainnya tidak stasioner pada tingkat level. Maka dari itu dilakukanlah pengujian first difference. Apabila salah satu dilakukan uji first difference, maka variabel lain pun harus dikenakan uji tersebut.

\section{Uji Kointegrasi (Bound Test)}

Tabel 3: Hasil Uji Kointegrasi

\begin{tabular}{|c|c|c|}
\hline Test Statistic & Value & K \\
\hline F-Statistics & 6.144582 & 4 \\
\hline \multicolumn{3}{|c|}{ Critical Value Bounds } \\
\hline Significance & IO Bound & I1 Bound \\
\hline $10 \%$ & 2.45 & 3.52 \\
\hline $5 \%$ & 2.86 & 4.01 \\
\hline $2.50 \%$ & 3.25 & 4.49 \\
\hline $1 \%$ & 3.74 & 5.06 \\
\hline
\end{tabular}

Sumber: World Bank, diolah

Berdasarkan Tabel di atas menunjukkan hasil kointegrasi pada metode ARDL. Tabel tersebut menunjukkan bahwa nilai $F$ stastistik sebesar 6.144 sedangkan nilai kritis Bounds 
pada tingkat 5 persen, yaitu 10 bound sebesar 2.846 dan 11 bound sebesar4.01. Nilai F statistic tersebut lebih besar dari nilai 10 bound dan I1 bound sehingga terdapat kointegrasi antar variabel dalam model ARDL.

\section{Hasil Estimasi ARDL}

Tabel 4: Hasil Estimasi ARDL

\begin{tabular}{|c|c|c|c|c|}
\hline Variable & Coefficient & Std. Error & t-Statistic & Prob* \\
\hline$Y(-1)$ & 0.576071 & 0.106294 & 5.419593 & 0.0000 \\
\hline $\mathrm{X} 1$ & -0.095537 & 0.036926 & -2.587230 & 0.0162 \\
\hline $\mathrm{X} 1(-1)$ & -0.084824 & 0.035396 & -2.396429 & 0.0247 \\
\hline $\mathrm{X} 1(-2)$ & 0.175588 & 0.034736 & 5.054903 & 0.0000 \\
\hline LX2 & 0.003249 & 0.003524 & 0.921854 & 0.3658 \\
\hline X3 & -0.044043 & 0.073691 & -0.597670 & 0.5557 \\
\hline $\mathrm{X} 3(-1)$ & -0.018496 & 0.071279 & -0.259489 & 0.7975 \\
\hline$X 3(-2)$ & -0.176875 & 0.069600 & -2.541312 & 0.0179 \\
\hline $\mathrm{X} 3(-3)$ & 0.049127 & 0.048739 & 1.007948 & 0.3235 \\
\hline X3(-4) & -0.176062 & 0.051104 & -3.445398 & 0.0021 \\
\hline LX4 & -0.028328 & 0.017312 & -1.636337 & 0.1148 \\
\hline $\operatorname{LX} 4(-1)$ & -0.016237 & 0.019068 & -0.851548 & 0.4029 \\
\hline $\operatorname{LX} 4(-2)$ & 0.047543 & 0.016051 & 2.962066 & 0.0068 \\
\hline $\mathrm{C}$ & 0.001320 & 0.065181 & 0.020254 & 0.9840 \\
\hline R-squared & 0.942524 & \multicolumn{2}{|c|}{ Mean dependent var } & 0.054845 \\
\hline Adjusted R-squared & 0.911392 & \multicolumn{2}{|c|}{ S.D. dependent var } & 0.027290 \\
\hline S.E. of regression & 0.008124 & \multicolumn{2}{|c|}{ Akaike info criterion } & -6.510795 \\
\hline Sum squared residual & 0.001584 & \multicolumn{2}{|c|}{ Schwarz criterion } & -5.907474 \\
\hline Log likelihood & 137.705100 & \multicolumn{2}{|c|}{ Hannah-Quinn criter } & -6.296138 \\
\hline F-statistic & 30.274550 & \multicolumn{2}{|c|}{ Durbin-Watson stat } & 2.525852 \\
\hline Prob(F-statistic & 0.000000 & & & \\
\hline
\end{tabular}

Sumber: World Bank, diolah

Keterangan:

$$
\begin{array}{ll}
y & =\text { Tingkat pengangguran } \\
x_{1} & =\text { suku bunga riil } \\
x_{2} & =\text { permintaan uang riil } \\
x_{3} & =\text { pertumbuhan ekonomi } \\
x_{4} & =\text { nilai tukar riil rupiah/usd } \\
L & =\text { logaritma natural }
\end{array}
$$

Berdasarkan hasil estimasi ARDL pada tabel di atas dapat diketahui bahwa varuabel tingkat pengangguran pada lag 1 berpengaruh signifikan positif terhadap tingkat pengangguran dengan nilai koefisien 0,576071. Variabel suku bunga riil nerpengaruh negatif signifikan terhadap tingkat pengangguran dengan koefisien -0,095537, serta variabel suku bunga riil pada lag 1 berpengaruh negatif signifikan terhadap tingkat pengangguran dengan nilai koefisien sebesar $-0,084824$. Selanjutnya, variabel suku bunga riil pada lag 2 berpengaruh positif signifikan terhadap tingkat pengangguran dengan nilai koefisien sebesar 0,175588 . Variabel per- 
tumbuhan ekonomi pada lag 2 dengan nilai koefisien sebesar -0,176875 berpengaruh negatif signifikan terhadap tingkat pengangguran. Selanjutnya, variabel pertumbuhan ekonomi pada lag 4 dengan nilai koefisien sebesar $-0,176072$ berpengaruh negatif signifikan terhadap tingkat pengangguran. Variabel nilai tukar riil pada lag 2 dengan nilai koefisien sebesar 0,047543 berpengaruh negatif signifikan terhadap tingkat pengangguran.

\section{Hasil Estimasi Jangka Panjang dan Jangka Pendek}

Hasil estimasi jangka panjang dalam penelitian ini adalah sebagai berikut:

Tabel 5: Hasil Estimasi Jangka Panjang

\begin{tabular}{ccccc}
\hline Variable & Coefficient & Std. Error & t-Statistic & Prob \\
\hline X1 & -0.011258 & 0.136441 & -0.082516 & 0.9349 \\
\hline LX2 & 0.007663 & 0.007926 & 0.966760 & 0.3433 \\
\hline X3 & -0.864201 & 0.380676 & -2.270173 & 0.0325 \\
\hline LX4 & 0.007024 & 0.018404 & 0.381651 & 0.7061 \\
\hline C & 0.003114 & 0.153855 & 0.020241 & 0.9840 \\
\hline
\end{tabular}

Sumber: World Bank, diolah

Keterangan:

$$
\begin{array}{ll}
y & =\text { Tingkat pengangguran } \\
x_{1} & =\text { suku bunga riil } \\
x_{2} & =\text { permintaan uang riil } \\
x_{3} & =\text { pertumbuhan ekonomi } \\
x_{4} & =\text { nilai tukar riil rupiah/usd } \\
L & =\text { logaritma natural }
\end{array}
$$

Berdasarkan pada tabel di atasdapat dijelaskan bahwa hanya variabel pertumbuhan ekonomi yang berdampak negatif signifikan terhadap tingkat pengangguran di Indonesia selama masa tahun yang diteliti dalam jangka panjang. Variabel suku bunga riil, permintaan uang riil, dan nilai tukar riil rupiah/USD tidak berpengaruh signifikan terhadap tingkat pengangguran di Indonesia pada tahun 1975-2016 dalam jangka panjang.

Tabel 6: Hasil Estimasi Jangka Pendek

\begin{tabular}{ccccc}
\hline \multicolumn{5}{c}{ Cointegrating Form } \\
\hline Variable & Coefficient & Std. Error & t-Statistic & Prob \\
\hline $\mathrm{D}(\mathrm{X} 1)$ & -0.095537 & 0.036926 & -2.587230 & 0.0162 \\
\hline $\mathrm{D}(\mathrm{X} 1(-1))$ & -0.175588 & 0.034736 & -5.054903 & 0.0000 \\
\hline $\mathrm{D}(\mathrm{LX} 2)$ & 0.003249 & 0.003524 & 0.921854 & 0.3658 \\
\hline $\mathrm{D}(\mathrm{X} 3)$ & -0.044043 & 0.073691 & -0.597670 & 0.5557 \\
\hline $\mathrm{D}(\mathrm{X} 3(-1))$ & 0.176875 & 0.069600 & 2.541312 & 0.0179 \\
\hline $\mathrm{D}(\mathrm{X} 3(-2))$ & -0.049127 & 0.048739 & -1.007948 & 0.3235 \\
\hline $\mathrm{D}(\mathrm{X} 3(-3))$ & 0.176072 & 0.051104 & 3.445398 & 0.0021 \\
\hline $\mathrm{D}(\mathrm{LX} 4)$ & -0.028328 & 0.017312 & -1.636337 & 0.1148 \\
\hline $\mathrm{D}(\mathrm{LX} 4(-1))$ & -0.047543 & 0.016051 & -2.962066 & 0.0068 \\
\hline $\mathrm{CointEq}(-1)$ & -0.423929 & 0.106294 & -3.988266 & 0.0005 \\
\hline$S$ m & & & & \\
\hline
\end{tabular}

Sumber: World Bank, diolah 


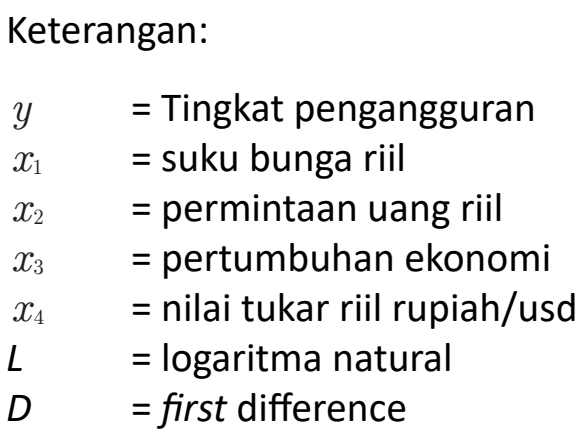

Berdasarkan hasil dari tabel di atas maka dapat diketahui bahwa variabel suku bunga riil berpengaruh negatif signifikan terhadap tingkat pengangguran dalam jangka pendek. Variabel suku bunga riil pada lag 1 berpengaruh negatif signifikan terhadap tingkat pengangguran dalam jangka pendek. Selanjutnya, Variabel pertumbuhan ekonomi pada lag 1 berpengaruh negatif signifikan terhadap tingkat pengangguran dalam jangka pendek. Variabel pertumbuhan ekonomi pada lag 3 berpengaruh negatif signifikan terhadap tingkat pengangguran dalam jangka pendek. Selanjutnya, variabel nilai tukar riil pada lag 1 berpengaruh negatif signifikan terhadap tingkat pengangguran dalam jangka pendek.

\section{Pembahasan}

\section{Pengaruh Suku Bunga Riil Terhadap Tingkat Pengangguran}

Analisis jangka panjang menunjukkan nilai probabilitas variabel suku bunga riil tidak berpengaruh signifikan terhadap tingkat pengangguran. Analisis jangka pendek juga menunjukkan berpengaruh negatif signifikan terhadap tingkat pengangguran dalam jangka pendek. Hasil studi ini didukung penelitian Doğan (2012) yang menunjukkan suku bunga riil berpengaruh negatif signifikan terhadap tingkat pengangguran. Hasil studi ini juga didukung oleh Benazić \& Rami (2016) yang menunjukkan suku bunga tidak berpengaruh signifikan terhadap tingkat pengangguran.

Hasil studi ini menunjukkan bahwa suku bunga riil tidak memiliki pengaruh yang signifikan terhadap tingkat pengangguran dalam jangka panjang. Hasil ini menunjukkan bahwa instrumen kebijakan moneter dengan suku bunga kurang berperan dalam mempengaruhi tingkat pengangguran di Indonesia dan industri perbankan masih lambat dalam merespon penurunan perubahan suku bunga. Suku bunga riil tidak berpengaruh signifikan terhadap tingkat pengangguran di Indonesia karena tingkat pengangguran di Indonesia muncul didorong masalah jumlah penduduk yang tinggi, kesempatan kerja yang sempit, kompetensi pencari kerja tidak sesuai dengan pasar kerja, ketimpangan pendapatan, tekanan kenaikan upah di tengah dunia usaha yang masih lesu (Utomo, 2013). Faktor lain yaitu tingkat inflasi yang mempengaruhi nilai suku bunga riil selalu distabilkan dalam jangka panjang sehingga tidak mengakibatkan penurunan daya beli, sebab penurunan daya beli akan mengurangi permintaan produk.

\section{Pengaruh Permintaan Uang Riil Terhadap Tingkat Pengangguran}

Analisis jangka panjang dan jangka pendek menunjukkan nilai probabilitas permintaan uang riil di atas tingkat signifikasi lima persen. Hal ini menunjukkan bahwa variabel permintaan uang tidak berpengaruh signifikan tterhadap tingkat pengangguran. Hasil penelitian ini sejalan dengan penelitian Loganathan dkk. (2012) menunjukkan bahwa kebijakan moneter dengan instrument jumlah uang yang beredar tidak berpengaruh signifikan terhadap tingkat pengangguran di negara Malaysia. Menurut Loganathan dkk. (2012) pengangguran di negara 
Malaysia karena turn-over effect yang muncul pada pasar kerja Malaysia, dimana penjcari kerja berpendidikan tinggi bersaing dengan berpendidikan rendah dengan angkatan kerja berpengalaman. Selain itu, jumlah tenaga kerja yang digunakan di sektor pertanian dan manufaktur di Malaysia menurun karena teknologi yang digunakan pada lini produksi dan luapan tenaga kerja asing.

Masalah pengangguran telah lama dikenal sebagai salah satu penyakit utama Indonesia. Kenaikan pengangguran selalu menyertai pelemahan aktivitas ekonomi. Romer \& Romer (2004) berpendapat bahwa kebijakan moneter telah menjadi variabel kunci untuk mengurangi tingkat pengangguran. Reaksi kebijakan moneter penting dalam memahami perilaku pengangguran dari waktu ke waktu (Stockhammer \& Sturn, 2012) Bank Indonesia mengimplementasikan kebijakan moneter ekspansif akan merangsang ekonomi domestik dan mengurangi pengangguran. Pengaruh kebijakan moneter terhadap pengangguran tidak akan berdampak secara langsung, namun butuh waktu. Kebijakan moneter ekspansif membuat suku bunga turun sehingga para investor akan tertarik untuk berinvestasi. Dengan bertambahnya investasi maka akan memberikan peningkatan terhadap pengeluaran agregat sehingga akan meningkatkan pendapatan nasional. Pendapatan nasional yang meningkat akan diikuti dengan naiknya permintaan agregat. Untuk bisa memenuhi permintaan yang meningkat tersebut maka produsen akan menambah tenaga kerja agar output yang dihasilkan meningkat. Dengan demikian maka penyerapan tenaga kerja akan terjadi dan mengurangi pengangguran.

\section{Pengaruh Pertumbuhan Ekonomi Terhadap Tingkat Pengangguran}

Analisis jangka panjang dan jangka pendek menunjukkan nilai probabilitas variabel pertumbuhan ekonomi di bawah tingkat signifikan 5\%. Hal ini menunjukkan bahwa variabel pertumbuhan ekonomi berpengaruh signifikan terhadap tingkat pengangguran. Hasil ini sejalan dengan penelitian Doğan (2012) yang menunjukkan pertumbuhan ekonomi berpengaruh signifikan terhadap tingkat pengangguran. Doğan (2012) menyatakan bahwa peningkatan pertumbuhan ekonomi yang berkelanjutan akan membuka lapangan pekerjaan yang lebih luas sehingga tingkat pengangguran semakin berkurang.

Besar atau kecil pertumbuhan ekonomi dapat mempengaruhi jumlah pengangguran. Hubungan antara pengangguran dengan pertumbuhan ekonomi dapat dijelaskan melalui hukum Okun. Berdasarkan hukum Okun, jumlah pengangguran berhubungan negatif dengan tingkat pendapatan (Iswanto, 2013). Hukum Okun menyatakan bahwa setiap kenaikan pertumbuhan ekonomi dapat menurunkan tingkat pengangguran (Samuelson \& Nordhaus, 2010:365). Adanya pertumbuhan ekonomi yang mendekati 2 persen akan mengurangi pengangguran sebesar 1 persen (Mankiw, 2009:186).

\section{Pengaruh Nilai Tukar Riil Terhadap Tingkat Pengangguran}

Pengaruh nilai tukar terhadap tingkat pengangguran tergantung pada karakteristik pasar tenaga kerja. Secara khusus, Andersen \& Sørensen (1988) berpendapat bahwa jika serikat buruh kuat, nilai tukar stabil dapat menyebabkan kenaikan upah yang berlebihan, maka lowering employment. Belke \& Kaas (2004) berpendapat bahwa jika kekakuan pasar tenaga kerja meningkatkan posisi tawar pekerja, sehingga meningkatkan upah dan lowering the net return to firms, nilai tukar yang terdepresiasi mendorong perusahaan untuk menunda penciptaan lapangan ternaga kerja sehingga tingkat pengangguran semakin tinggi. 
Nilai tukar riil rupiah/USD berpengaruh signifikan terhadap tingkat pengangguran dalam jangka pendek. Signifikasi variabel nilai tukar riil rupiah/USD terhadap tingkat pengangguran menunjukkan bahwa nilai tukar riil rupiah/USD berperan dalam menentukan tingkat pengangguran di Indonesia. Hasil ini menunjukkan bahwa nilai tukar dapat mengubah harga relatif input dan output menjadi lebih murah atau lebih mahal, sehingga nilai tukar terkadang digunakan sebagai alat untuk meningkatkan output atau menurunkan output dan berdampak pada penyerapan tenaga kerja. Sistem nilai tukar mengambang yang dianut oleh Indonesia mengakibatkan nilai tukar mengalami depresiasi atau apresiasi. Nilai tukar rupiah mengalami depresiasi maka mengganggu perusahan yang berbahan baku impor. Dollar US secara terus menerus mengalami apresiasi dibandingkan dengan rupiah maka akan terjadi kenaikan harga barang impor. Kondisi ini membuat perusahaan yang menggunakan bahan baku impor terancam gulung tikar sehingga terjadi pemutusan hubungan kerja lebih banyak dan meningkatkan pengangguran.

\section{Kesimpulan}

Pertumbuhan ekonomi berdampak negatif signifikan terhadap tingkat pengangguran di Indonesia pada 1975-2016 dalam jangka panjang. Nilai koefisien pertumbuhan ekonomi menunjukkan hubungan yang negatif dan sesuai dengan hukum Okun bahwa tingkat pengangguran dan output berhubungan negatif dimana kenaikan pertumbuhan ekonomi sebesar satu persen maka akan menurunkan tingkat pengangguran sebesar $0.86 \%$. Sedangkan, dalam jangka pendek suku bunga riil, suku bunga riil pada lag 1, pertumbuhan ekonomi pada lag 1 dan lag 3, serta nilai tukar riil pada lag 1memiliki pengaruh negatif signifikan terhadap tingkat pengangguran. Nilai koefisien dari semua variabel tersebut menunjukkan hubungan yang negatif dan signifikan pada periode 1975-2016 dalam jangka pendek. Hal ini menandakan bahwa dampak yang diberikan oleh kebijakan moneter kepada tingkat penggangguran bersifat temporer.

Bank Indonesia selaku otoritas moneter diharapkan dapat mengendalikan pertumbuhan jumlah uang beredar dengan cara operasi pasar terbuka atau menghimbau perbankan pemberi kredit untuk berhati-hati dalam mengeluarkan kredit serta menjaga inflasi agar tidak melebihi target yang ditetapkan. Selain itu, Bank Indonesia diharapkan dapat mengendalikan suku bunga sesuai dengan kondisi ekonomi yang berlaku di Indonesia, serta melakukan kebijakan menjaga stabilitas nilai tukar IDR/USD dengan cara mendorong peningkatan ekspor dan mengurangi impor. Selanjutnya, Pemerintah dan Bank Indonesia diharapkan dapat menjaga stabilitas ekonomi makro. Penelitian selanjutnya sebaiknya menggunakan variabel jumlah uang beredar dan memasukan faktor lain seperti UMR. Terdapat beberapa keterbatasan dalam penelitian ini diantaranya adalah data time series yang digunakan berupa tahun, alangkah lebih baik berupa kuartal. Selain itu, penelitian selanjutnya diharapkan dapat menggunakan metode lain seperti VECM.

\section{Daftar Pustaka}

Akanbi, O. B. (2015). Impact of Macroeconomic Variables on Nigerian Unemployment using the Vector Autoregressive Approach. International Journal of Research in Humanities and Social Studies, 2(June), 65-76.

Andersen, T. M., \& Sørensen, J. R. (1988). Exchange rate variability and wage formation in open economies. Economics Letters, 28(3), 263-268.

Bakhshi, Z., \& Ebrahimi, M. (2016). MARKETING AND BRANDING RESEARCH The effect of real 
exchange rate on unemployment. Marketing and Branding Research, 3(1), 4-13.

Belke, A., \& Kaas, L. (2004). Exchange rate movements and employment growth: An OCA assessment of the CEE economies. Empirica, 31(2-3), 247-280.

Benazić, M., \& Rami, J. (2016). Monetary policy and unemployment in Croatia. Economic Research-Ekonomska Istrazivanja , 29(1), 1038-1049.

Blanchard, O. (2017). Macroeconomics (Seventh Edition). Boston. Pearson.

Doğan, T. T. (2012). Macroeconomic variables and unemployment: The case of Turkey. International Journal of Economics and Financial Issues, 2(1), 71-78.

Galí, J. (2012). Unemployment fluctuations and stabilization policies: a new Keynesian perspective. Choice Reviews Online, 49(06).

Gujarati, D. N., \& Dawn C. Porter (2003). Basic Econometrics (Fourth Edition). New York. The McGrawHill Companies, Inc.

Iswanto, D. A. (2013). Validitas Hukum Okun Di Indonesia. Ekonomi, Pertumbuhan Pengangguran, D A N IImiah.

Karomah, A., \& Suhartono. (2014). Peramalan Netflow Uang Kartal dengan Model. Jurnal Sains Dan Seni Pomits, 3(2), 103-108.

Kauffman, B. E., \& Hotchkiss, J. L. (1999). The Economics of Labor Market (Fifth Edition). USA: The Dryden Press. Harcourt College Publisher.

Lindiarta, A. (2014). Analisis Pengaruh Tingkat Upah Minimum, Inflasi , Dan Jumlah Penduduk terhadap Pengangguran di Kota Malang (1996-2013). Jurnal IImiah Mahasiswa FEB Universitas Brawijaya.

Loganathan, N., Sultan, U., Abidin, Z., \& Kogid, M. (2012). Monetary Policy and Unemployment Shocks in Malaysia : Do They Connect? 3rd International Conference On Business And Economic Research (3Rd Icber 2012) Proceeding, March.

Mankiw, G. N. (2009). Macroeconomics (Seventh Edition). New York. Worth Publishers.

Musianto, L. S. (2002). Perbedaan Pendekatan Kuantitatif Dengan Pendekatan Kualitatif Dalam Metode Penelitian. Jurnal Manajemen Dan Kewirausahaan, 4(2), 123-136.

Pesaran, M. H., Shin, Y., \& Smith, R. J. (2001). Bounds testing approaches to the analysis of level relationships. Journal of Applied Econometrics, 16(3), 289-326.

Pitartono, R. (2012). Analisis Tingkat Penganggurran di Jawa Tengah Tahun 1997-2010. Ekonomi Pembangunan.

Prasetyo, A. S. (2018). Determinants of Demand For Money and The Velocity of Money in Indonesia. Journal of Developing Economies, 3(2), 10.

Romer, C. D., \& Romer, D. H. (2004). A New Measure of Monetary Shocks: Derivation and Implications. American Economic Review, 94(4), 1055-1084.

Samuelson, P. A., \& Nordhaus, W. A. (2010). Economics (Nineteenth Edition). New York. The McGrawHill Companies, Inc.

Stockhammer, E., \& Sturn, S. (2012). The impact of monetary policy on unemployment hyster- 
esis. Applied Economics, 44(21), 2743-2756.

Sukirno, Sadono. 2003. Ekonomi Pembangunan : Proses, Masalah, dan Dasar Kebijaksanaan. Edisi Pertama. Jakarta: LPFE : UI Bima Grafika.

Utomo, F. W. (2013). Pengaruh Inflasi dan Upah Terhadap Penangguran Di Indonesia Periode Tahun 1980-2010. Jurnal IImiah, 1-22. 